\title{
Correlation analysis between orientation and energy consumption of semi-underground ski slope in hot summer and cold winter region
}

\author{
Zhi Wu ${ }^{1}$, Chengjun Tang ${ }^{2}$, Wei Zhang ${ }^{2 *}$, Wenjuan Liu $^{3}$ \\ ${ }^{1}$ 3rd Construction Co, Ltd of China Construction 5th Engineering Bureau, Changsha 410004, China \\ ${ }^{2}$ School of Architecture, Hunan University, Changsha 410082, China \\ ${ }^{3}$ Hunan Institute of Science and Technology, College of Civil Engineering \& Architecture, Yueyang 414000, China
}

Corresponding Author Email: 413818645@qq.com

https://doi.org/10.18280/ijht.360239

Received: 10 October 2017

Accepted: 20 Febuary 2018

\author{
Keywords: \\ hot summer and cold winter region, semi- \\ underground ski slope (SUSS), \\ quantitative analysis, orientation, energy \\ consumption
}

\begin{abstract}
This paper aims to disclose the correlation between orientation and energy consumption of semi-underground ski slope (SUSS) in hot summer and cold winter region. For this purpose, the Design Builder software was adopted to simulate the energy consumption of a typical SUSS in the target region at different orientations. Through quantitative and qualitative analysis, it is concluded that the SUSS consumes more energy in summer than in winter; the energy consumption reaches the minimum at the azimuth of $300^{\circ}$ and the maximum at $120^{\circ}$. The research findings lay a theoretical basis for the design standard and regulation of the SUSS and shed new light on the energy-saving design of buildings.
\end{abstract}

\section{INTRODUCTION}

Ski slope is an emerging type of public building that integrate sports, leisure, entertainment and business functions into a whole. With the promotion of skiing, ski slopes are springing up in major cities. However, ski slope consumes more energy than many other public buildings, owing to its huge scales and large temperature difference between indoor and outdoor. In China, there is no official standard or regulation on the design, construction and operation of large public buildings like ski slope, not to mention the technical guide on the design of energy-saving ski slopes. With the growing awareness of energy conservation and emission reduction, it is very meaningful to explore the energy-saving design of ski slopes.

In foreign countries, the construction of ski slopes can be traced back to 40 years ago. Since then, numerous ski slopes have been built in major cities across the world, especially in Europe [1-4]. The techniques related to indoor dry ski slopes have been frequently elaborated in the United States Patent. For instance, several patents were released in 1990 on the support system of dry ski slopes, including some drawings and structure techniques [5-6]; a special track structure was designed for dry ski slopes and the concept of integrated track was proposed in 1993; the patents on diversified track patterns and indoor lighting design were issued in 2002. According to the Indoor Ski Slope (WO 2006/062396 Al) published by the World Intellectual Property Organization, the track temperature should be maintained between $-5^{\circ} \mathrm{C}$ and $-9^{\circ} \mathrm{C}$ to achieve the optimal condition of the snow [7-9].

Currently, there are only a few reports on ski slope in China. Focusing on Qiaobo Ice \& Snow World in Beijing, Du Shuang, Zhang Kui, Zhuang Weimin et al. published a series of papers, namely, the "Creation under Constraints: Inspirations from the Façade Design of Qiaobo Ice \& Snow World", "Preliminary Study on the Design of Indoor Ski Slope", "Air-Conditioning
Design for Indoor Ski Slope" [10], "Relationship between Fogging and Humidity-Temperature Distribution in Indoor Ski Slope" [11], "Energy-Saving Thermal Design of Ski Slope" [12], "Ecological Design of Ice and Snow Sports Buildings" [13], and "Energy-Saving Design of Fresh Air Dehumification in Recreational Indoor Artificial Ice Stadiums" [14]. In addition, Chen Hua and Zou Tonghua from Tianjin University of Commerce published an academic thesis the "Design and Energy Conservation of Indoor Dry Ski Slope". These studies mainly tackle the following issues: Taking Qiaobo Ice \& Snow World as an example, the focal points of ski slope design were briefly described, including the architectural design, the design of the thermal insulation enclosure and the air-conditioning system; the energy-saving design was identified as the key to solving the ski slope problems not covered by the current laws and regulations; concerning the design and energy conservation of indoor dry ski slope, in-depth discussions were conducted on the component systems of the ski slope, the requirements on indoor temperature environment and the design of the air-conditioning system, and the determination of the cooling load.

To sum up, there is a severe lack of relevant research and reference for the construction of ski slope in China, and there are many problems concerning the energy-saving design in the operation of ski slope (e.g. substandard indoor environment and excessive energy consumption caused by improper design). This calls for standard technical guidance on the development of ski slope and other big energy consumers.

\section{ORIENTATION ANG ENERGY CONSUMPTIONS OF SEMI-UNDERGROUND SKI SLOPE (SUSS)}

\subsection{Energy consumption features of the SUSS}

The SUSS, consisting of a surface part and an underground 
part, is often built in rock formation or soil horizon.

\subsubsection{Energy consumption of the surface part}

There are many factors that influence the energy consumption of the air-conditioning system in ski slope. The objective, climate factors include temperature, solar radiation, humidity, and wind $[15,16]$, while the architectural factors refer to the construction measures against the negative effects of the climate, namely, the building orientation, the shape coefficient and the enclosure structure. To save energy, the orientation should maximize the use of sunlight in winter and reduce the exposure to the sun in summer. In the northern hemisphere, the solar illuminance peaks in the south direction in winter and in the east and west directions in summer. Therefore, the large surface of the façade should be oriented towards the south, while the small surface should be oriented towards the east and the west. This orientation design could lower the energy consumed for air conditioning. In general, the shape factor is positively correlated with the relative outer surface area of the building and the heat transfer amount of the building during air conditioning. There is a maximum limit of the shape factor in the standard for energy-saving design of buildings (GB 50189-2015), aiming to control the heat transfer amount through the area constraint on building shell. In severe cold region or cold region, the shape coefficient should be smaller than or equal to 0.5 if a single building covers $300 \sim 800 \mathrm{~m}^{2}$ and should be smaller than or equal to 0.4 if a single building covers more than $800 \mathrm{~m}^{2}$. The enclosure structure, including roof, outer wall and outer doors/windows, can block the impacts of outdoor climate and reduce indoor energy loss. Energy-saving design parameters are available for each component of the enclosure structure (Table 1).

\subsubsection{Energy consumption of the underground part}

The enclosure structure of the underground part (including the bedrock and base soil) can be regarded as a semi-infinite heat transfer medium, featuring good thermal stability, small indoor temperature variation and humidity in summer. The energy consumption of the underground part is affected by the ventilation condition, the use situation, the geometric condition, and the thermophysical properties of the enclosure. Specifically, the ventilation condition covers the intake air temperature, air rate, ventilation system, ventilation mode and air distribution; the use situation refers to the working condition of the indoor heat source and other issues; the geometric condition include the burial depth, the chamber size and the chamber geometry; the thermophysical properties of the enclosure stand for the thermal conductivity and diffusivity of the heat transfer medium-liner material, bedrock and base soil and the movements of fissure water.

Table 1. Thermal performance of enclosure structure in different regions

\begin{tabular}{|c|c|c|c|c|}
\hline & \multirow{2}{*}{$\begin{array}{c}\text { Facade } \\
\mathrm{W} /\left(\mathrm{m}^{2} \cdot \mathrm{K}\right)\end{array}$} & \multirow{2}{*}{$\begin{array}{c}\text { Outer wall (Non-transparent curtain } \\
\text { wall) } \\
\mathrm{W} /\left(\mathrm{m}^{2} \cdot \mathrm{K}\right)\end{array}$} & \multicolumn{2}{|c|}{$\begin{array}{l}\text { Outer window (including transparent curtain } \\
\text { wall) }\end{array}$} \\
\hline & & & Window-wall area ratio & $\mathrm{W} /\left(\mathrm{m}^{2} \cdot \mathrm{K}\right)$ \\
\hline \multirow{2}{*}{ Severe cold regions A and B } & \multirow{2}{*}{$\leq 0.35$} & \multirow{2}{*}{$\leq 0.45$} & $0.40<$ window-wall area ratio $\leq 0.60$ & $\leq 2.5$ \\
\hline & & & window-wall area ratio $>0.60$ & $\leq 2.2$ \\
\hline \multirow{2}{*}{ Severe cold region $\mathrm{C}$} & \multirow{2}{*}{$\leq 0.45$} & \multirow{2}{*}{$\leq 0.50$} & $0.40<$ window-wall area ratio $\leq 0.60$ & $\leq 2.6$ \\
\hline & & & window-wall area ratio $>0.60$ & $\leq 2.3$ \\
\hline \multirow{2}{*}{ Cold region } & \multirow{2}{*}{$\leq 0.55$} & \multirow{2}{*}{$\leq 0.60$} & $0.40<$ window-wall area ratio $\leq 0.70$ & $\leq 2.7$ \\
\hline & & & window-wall area ratio $>0.70$ & $\leq 2.4$ \\
\hline \multirow{2}{*}{$\begin{array}{l}\text { Hot summer and cold winter } \\
\text { region }\end{array}$} & \multirow{2}{*}{$\leq 0.70$} & \multirow{2}{*}{$\leq 1.0$} & $0.40<$ window-wall area ratio $\leq 0.70$ & $\leq 3.0$ \\
\hline & & & window-wall area ratio $>0.70$ & $\leq 2.6$ \\
\hline \multirow{2}{*}{$\begin{array}{l}\text { Hot summer and warm winter } \\
\text { region }\end{array}$} & \multirow{2}{*}{$\leq 0.90$} & \multirow{2}{*}{$\leq 1.5$} & $0.40<$ window-wall area ratio $\leq 0.70$ & $\leq 4.0$ \\
\hline & & & window-wall area ratio $>0.70$ & $\leq 3.0$ \\
\hline
\end{tabular}

\subsection{Effect of orientation on the energy consumption of the SUSS}

\subsubsection{Building orientation}

It is widely agreed that orientation directly bears on the energy conservation of buildings. Orientation means the angle between the façade normal and the south direction. To select a proper orientation, the following principles should be followed: in winter, the building should receive as much sunshine as possible and the main buildings should not face the prevailing wind direction; in summer, the heat from solar radiation should be minimized. Taking a north-south strip-shaped building as an example, a great amount of solar radiant heat is received in winter due to the variation in solar altitude and azimuth angle, and this trend is more obvious at a large façade area. In addition, the solar radiant heat of the building is relatively small in summer, with the main rooms not exposed to the sun in the east and west (Figure 1). To minimize the energy consumed for air conditioning, the strip-shape with north-south orientation or near north-south direction should be preferred whenever the general layout allows the free choice of the shape and orientation.

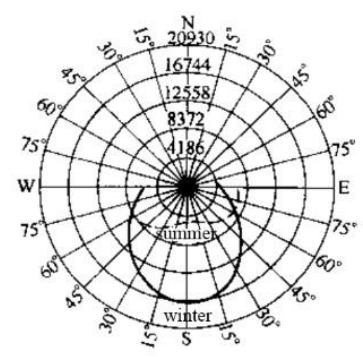

(a) Beijing;

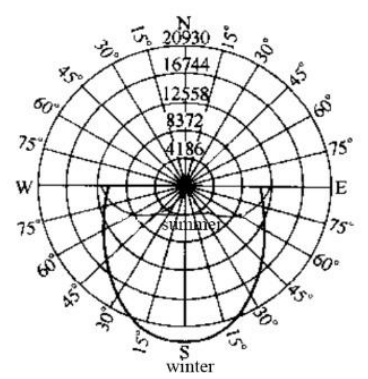

(b) Shanghai
Figure 1. Variation in total daily solar radiation

The energy-saving orientation should be determined considering the impacts from sunshine and ventilation. To obtain good sunshine, the most buildings in temperate and frigid zones are built in the north-south direction. This reflect the seasonal variation in the solar radiation intensity on building surfaces in different directions. In the northern hemisphere, the north-south buildings receive relatively few heats in hot summer and absorb lots of radiant heat in cold winter. In this way, the interior of these buildings is kept cool 
in summer and warm in winter. The traditional residential buildings in northern China all abide by the north-south principle, such as the quadrangle courtyards of Beijing, the courtyards in north-eastern China, and the courtyard houses in Shanxi Province. The wind pressure, the cause of the through draught, is the greatest when a building is vertical to the dominant wind direction. Nevertheless, this orientation does not necessarily produce the optimal mean wind speed or optimal air distribution inside the building. For occupants of the building, the human body can be cooled down most effectively at the maximum mean indoor wind speed, that is, the air must flow through all indoor areas. Suppose there are windows on opposite walls, the air will flow directly from the inlet to the outlet when the building is vertical to the dominant wind direction. In this case, nothing will happen to the indoor areas, except the local turbulence at the outlet. If the wind incidence angle is skewed by $45^{\circ}$, the mean indoor wind speed will be maximized and the indoor air distribution will be optimized. The effect of the wind parallel to the wall surface is completely dependent on the wind fluctuations and is therefore hard to determine.

\subsubsection{Orientation features}

In China, the indoor areas are colder than the outdoor throughout the year in both the hot summer and cold winter region and the hot summer and warm winter region. The solar radiation exerts a negative impact on energy conservation of ski slopes in both summer and winter. Therefore, the avoidance of summer radiation is the key to the energy conservation of ski slopes throughout the year.

The building surfaces in different direction consume different amounts of energy. The difference is positively correlated with the length-width ratio of the building plane. For the square building plane, there is basically no difference in the energy consumption of each orientation; for ski slopes with a large length-width ratio, the orientation difference in energy consumption is very prominent. In addition, most ski slopes adopt the single slope roof, which produces greater orientation difference in the roof energy consumption than the common flat roof. Thus, the orientation directly bears on the energy conservation of ski slopes. Table 2 lists the lengthwidth ratios of several ski slopes in China. It can be seen that these ratios, ranging between 3.3 and 7.5, are much greater than those of ordinary civil buildings. Under the same conditions, the different surfaces of a ski slope will inevitably vary with the orientations. In the planning of the general layout, the optimal or near optimal orientations must be designed according to the local conditions.

Table 2. Length-width ratio of some ski slopes

\begin{tabular}{|c|c|c|c|}
\hline name & $\begin{array}{c}\text { Length of snow } \\
\text { path }\end{array}$ & $\begin{array}{c}\text { Width of snow } \\
\text { path }\end{array}$ & $\begin{array}{l}\text { Ratio of length to } \\
\text { width }\end{array}$ \\
\hline Shanghai silver Seven Star indoor skiing field & $380 \mathrm{~m}$ & $80 \mathrm{~m}$ & 4.8 \\
\hline Beijing Jo Bo Ice Snow World Ski Resort & $261 \mathrm{~m}$ & $40 m+40$ & 6.5 \\
\hline Shenzhen the Alps indoor ski resort & $114 \mathrm{~m}$ & $24 \mathrm{~m}$ & 4.8 \\
\hline Inner Mongolia Da Yong mountain indoor ski resort & $208 \mathrm{~m}$ & $45 \mathrm{~m}$ & 4.6 \\
\hline Chongqing fairmaidshan indoor ski resort & $243 \mathrm{~m}$ & $65 \mathrm{~m}$ & 3.7 \\
\hline Harbin Wan Da Mao indoor ski resort & $500 \mathrm{~m}$ & $150 \mathrm{~m}$ & 3.3 \\
\hline $\begin{array}{c}\text { Huangguoshu Waterfalls indoor ski resort, Anshun, } \\
\text { Guizhou }\end{array}$ & $300 \mathrm{~m}$ & $40 \mathrm{~m}$ & 7.5 \\
\hline
\end{tabular}

\section{QUANTITATIVE SIMULATION OF SUSS ORIENTATION AND ENERGY CONSUMPTION}

\subsection{Simulation software and parameter setting}

\subsubsection{Simulation software}

Table 3. Performance comparison of several common simulation software for energy consumption

\begin{tabular}{|c|c|c|c|c|c|}
\hline Name & Design Builder & DOE2 & Energy Plus & DeST & PKPM \\
\hline Developer & Design Builder & $\begin{array}{c}\text { Lawrence } \\
\text { Berkeley National } \\
\text { Laboratory } \\
\end{array}$ & $\begin{array}{c}\text { Lawrence Berkeley } \\
\text { National } \\
\text { Laboratory etc. } \\
\end{array}$ & $\begin{array}{c}\text { School of } \\
\text { Architecture, } \\
\text { Tsinghua University }\end{array}$ & $\begin{array}{l}\text { China Academy of } \\
\text { Building Research }\end{array}$ \\
\hline $\begin{array}{l}\text { Meteorological } \\
\text { parameters }\end{array}$ & $\begin{array}{l}\text { Auto loading of } \\
\text { meteorological } \\
\text { parameters }\end{array}$ & $\begin{array}{l}\text { Auto loading of } \\
\text { meteorological } \\
\text { parameters }\end{array}$ & $\begin{array}{l}\text { Auto loading of } \\
\text { meteorological } \\
\text { parameters }\end{array}$ & $\begin{array}{l}\text { Medpha } \\
\text { meteorological model }\end{array}$ & Unkown \\
\hline Strengths & $\begin{array}{l}\text { Powerful functions, } \\
\text { accurate calculation } \\
\text { and user-friendly } \\
\text { interface }\end{array}$ & $\begin{array}{l}\text { Powerful functions } \\
\text { and detailed } \\
\text { reports }\end{array}$ & $\begin{array}{c}\text { Powerful functions } \\
\text { and accurate } \\
\text { calculation }\end{array}$ & $\begin{array}{l}\text { Staged simulation for } \\
\text { different design } \\
\text { phases and easy to } \\
\text { operate }\end{array}$ & $\begin{array}{l}\text { Closely related to the } \\
\text { current codes for } \\
\text { building energy } \\
\text { conservation and easy } \\
\text { to operate }\end{array}$ \\
\hline Weaknesses & $\begin{array}{l}\text { Difficult to simulate } \\
\text { complex air- } \\
\text { conditioning systems }\end{array}$ & Hard to operate & Hard to operate & $\begin{array}{l}\text { Hidden dangers from } \\
\text { the fitted } \\
\text { meteorological data }\end{array}$ & Low accuracy \\
\hline
\end{tabular}

There are many two types of computer simulation software for building energy consumption. The first type is the simulation software of air-conditioning system, such as
TRNSYS, SPARP and HVACSIM. With powerful simulation programs for air-conditioning system, this type of simulation software is mainly adopted for simulation calculation of the 
operation of the air-conditioning system [17-19]. Despite the comprehensive simulation of the air-condition system, this type of software only supports a simple description of buildings. The second type of simulation software focuses on the description of the building and configures the airconditioning system based on the building model. Known for the building description function, this type of software is applicable to various building forms, suitable for simulation of the thermal features of buildings, and capable of computing the exact cumulative annual cooling/heating load. Compared to the first type of software, the second type of software only gives a simple depiction of the air-conditioning system. Typical examples of this type of software include Design Builder and DOE2. In this paper, the second type of software is adopted to simulate the energy consumption of the target buildings [20-21]. Table 3 compares the performance of common simulation software for energy consumption.

Considering the software features and energy consumption of ski slopes, Design Builder was adopted for the simulation in this research [22-23].

\subsubsection{Parameter setting}

This chapter selects a simplified energy consumption simulation model according to the scale of the SUSS [24, 25], aiming to facilitate the parameter setting and comparative analysis. The model only simulates the ski hall and ignores the space under the tracks. This is because the ski hall takes up the largest part and contributes the most energy consumption of the ski slope. The six surfaces of the model are all in direct contact with the atmosphere. The track length, width, height and gradient were set to $300 \mathrm{~m}, 30 \mathrm{~m}, 25 \mathrm{~m}$ and $8^{\circ}$, respectively (Figure 2). The same thermal parameters were configured for all outer surfaces, and the energy consumptions of them were compared under all energy-saving elements.

The ski hall must meet strict requirements on indoor environments like thermal environment, light environment, and visual environment. As the basic operation condition for the ski slope, the key requirement is to produce a high-quality snow layer of a certain thickness within a certain period of time and at a specific temperature. The ski slope shares many functional requirements with refrigeration house and skating rink. Considering the special features of ski slope, only the parameters of cooling and enclosure structure were configured for the simulation, while all the other parameters (e.g. personnel activity, ventilation status, office equipment, and domestic hot water) were not taken into account. The cooling temperature was set to the designed temperature of $-5^{\circ} \mathrm{C}$. The energy consumption simulation uses the climate data on typical meteorological yeas, including air temperature, total solar radiation, direct solar radiation, humidity, and wind speed. These data were directly downloaded from China's building energy-saving meteorological database, laying the basis for computing annual and monthly energy consumption. The database offers the climate data on typical meteorological yeas of most cities.

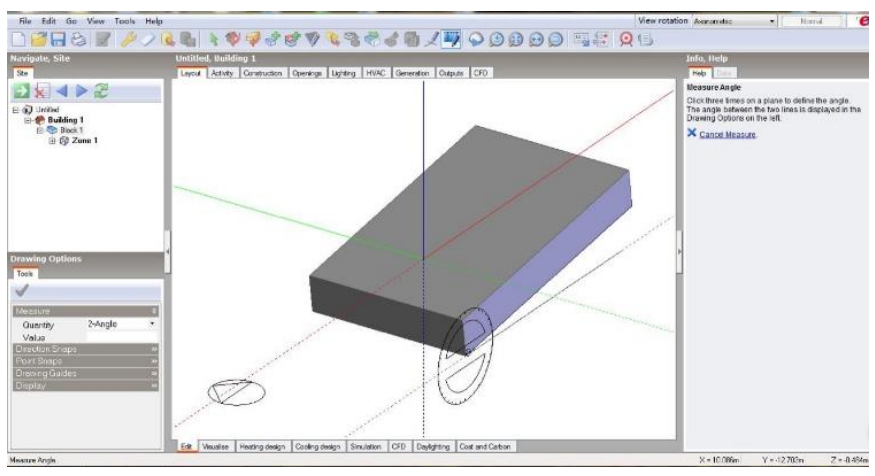

Figure 2. Simplified simulation model

\subsection{Results}

The climate in most parts of southern China is unfavourable for ski slopes throughout the entire year. Considering the seasonal variation in the direction of maximum solar radiation intensity, the optimal orientation of ski slope must be determined through comparison of energy consumptions on different surfaces. Here, the energy consumptions of ski slope are computed according to the climate conditions in Shanghai.

The basic model was adjusted to different directions under the same venue conditions. Taking the entrance of the ski hall, i.e., the lowest point of the ski slope, as the centre, the building was rotated 12 times at an interval of $30^{\circ}$, and the energy consumption at each direction was simulated. The ski slope was lower in the west and higher in the east at the azimuth of $0^{\circ}$, lower in the north and higher in the south at the azimuth of $90^{\circ}$, lower in the east and higher in the west at the azimuth of $180^{\circ}$, and lower in the south and higher in the north at the azimuth of $270^{\circ}$

Table 4. Monthly variation of energy consumption with orientations $\left(\mathrm{KWh} / \mathrm{m}^{2}\right)$

\begin{tabular}{ccccccccccccc}
\hline & 0 & 30 & 60 & 90 & 120 & 150 & 180 & 210 & 240 & 270 & 300 & 330 \\
\hline January & 34.29 & 34.23 & 34.2 & 34.18 & 34.2 & 34.22 & 34.28 & 34.27 & 34.26 & 34.265 & 34.27 & 34.265 \\
February & 32.7 & 32.68 & 32.64 & 32.65 & 32.66 & 32.67 & 32.71 & 32.69 & 32.68 & 32.70 & 32.71 & 32.72 \\
March & 43.245 & 43.22 & 43.21 & 43.24 & 43.22 & 43.23 & 43.24 & 43.23 & 43.25 & 43.29 & 43.28 & 43.27 \\
April & 62.77 & 62.78 & 62.80 & 62.82 & 62.81 & 62.79 & 62.78 & 62.81 & 62.84 & 62.87 & 62.85 & 62.8 \\
May & 79.12 & 79.14 & 79.17 & 79.18 & 79.17 & 79.14 & 79.12 & 79.15 & 79.18 & 79.19 & 79.18 & 79.14 \\
June & 80.6 & 80.63 & 80.66 & 80.67 & 80.66 & 80.63 & 80.59 & 80.63 & 80.66 & 80.67 & 80.66 & 80.63 \\
July & 105.6 & 105.64105 .68105 .69105 .68105 .63 & 105.6 & 105.64105 .68 & 105.7 & 105.69105 .64 \\
August & 99.15 & 99.16 & 99.23 & 99.25 & 99.24 & 99.19 & 99.14 & 99.19 & 99.26 & 99.3 & 99.29 & 99.24 \\
September & 85.77 & 85.76 & 85.77 & 85.78 & 85.77 & 85.76 & 85.765 & 85.79 & 85.81 & 85.82 & 85.8 & 85.78 \\
October & 76.07 & 76.03 & 76.01 & 76.02 & 76.02 & 76.04 & 76.07 & 76.07 & 76.08 & 76.10 & 76.09 & 76.08 \\
November & 54.74 & 53.69 & 53.65 & 53.64 & 53.65 & 53.68 & 53.72 & 53.715 & 53.71 & 53.72 & 53.72 & 53.72 \\
December & 42.55 & 42.45 & 42.38 & 42.34 & 42.36 & 42.45 & 42.52 & 42.51 & 42.45 & 42.47 & 42.48 & 42.56 \\
\hline
\end{tabular}




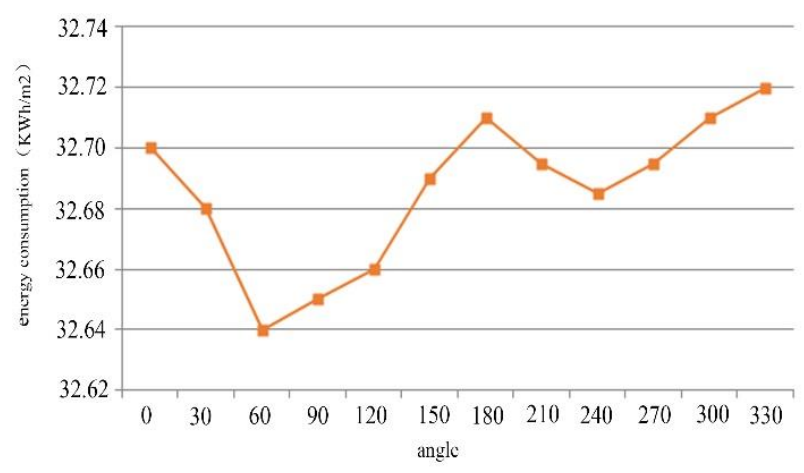

(a) Variation of energy consumption with orientations in February;

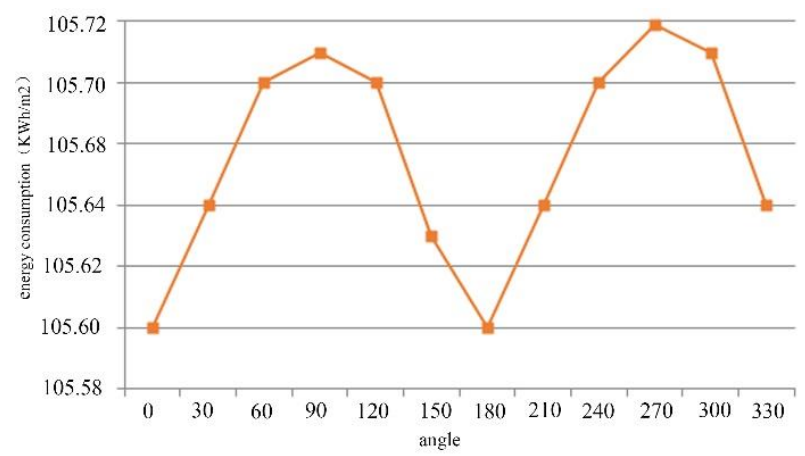

(c) Variation of energy consumption with orientations in July;

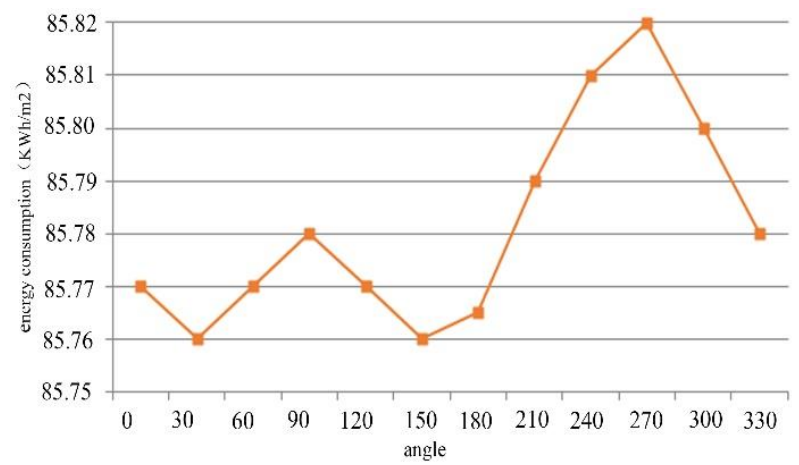

(e) Variation of energy consumption with orientations in September;

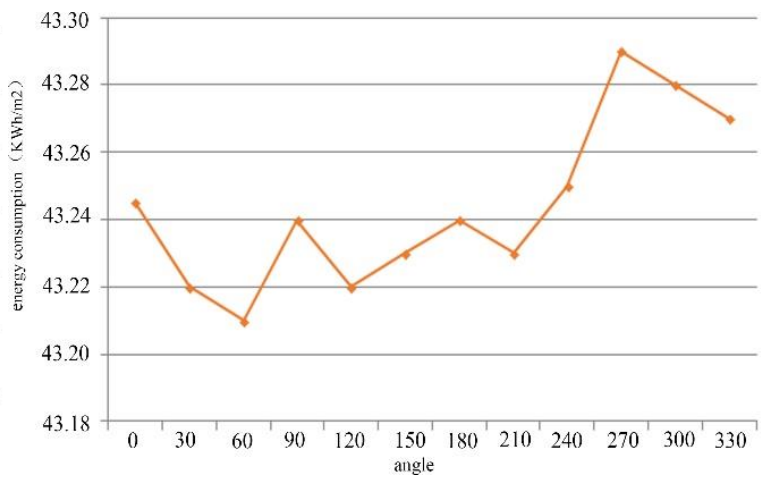

(b) Variation of energy consumption with orientations in March;

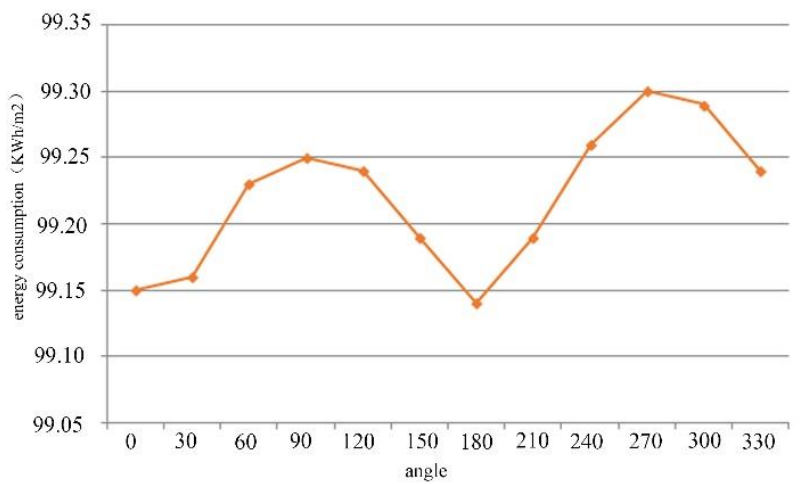

(d) Variation of energy consumption with orientations in August;

Figure 3. Monthly variation of energy consumption with orientations in typical months

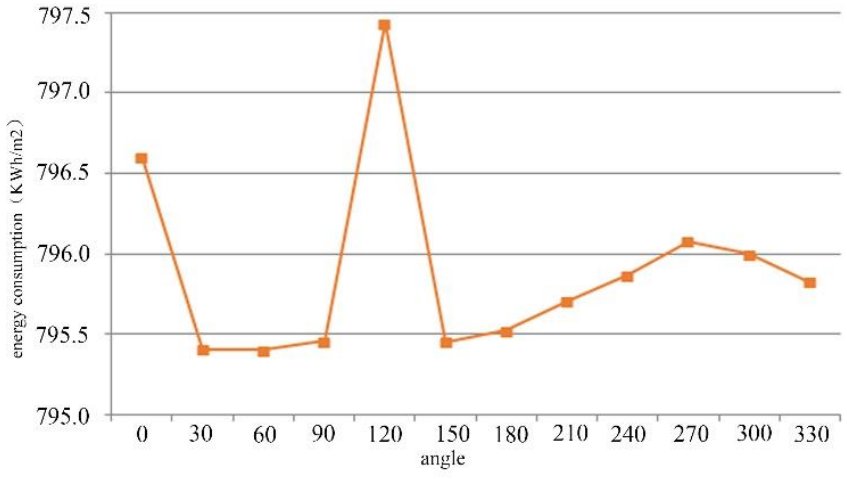

Figure 4. Total annual energy consumption at each azimuth angle

Table 4 shows the energy consumption of each orientation throughout the year. It is clear that the building energy consumption differed with the orientations in each month.

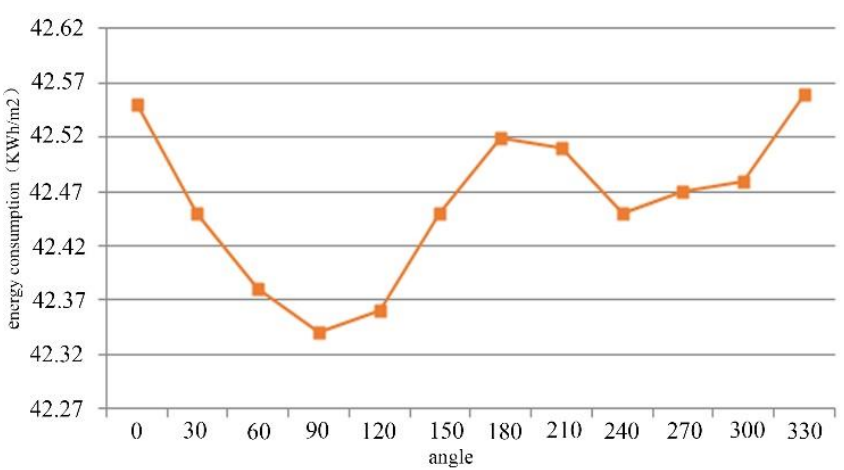

(f) Variation of energy consumption with orientations in December.
Every month, there was an orientation with the least energy consumption: $90^{\circ}$ in January, November, and December; $60^{\circ}\left(120^{\circ}\right)$ in February, March and October; $0^{\circ}\left(180^{\circ}\right)$ from April through August; $150^{\circ}$ in September (Figure 3). In winter, the energy consumption was lowest at $90^{\circ}$, when the ski slope was lower in the north and higher in the south; In summer, the energy consumption was lowest at $180^{\circ}$, when the ski slope was lower in the east and higher in the west.

According to the statistics on the yearly energy consumption of each orientation, the ski slope consumed the least energy in a year at the azimuth of $300^{\circ}$, when the slope is lower in the north by west and higher in the south by the east, rather than $90^{\circ}$ or $180^{\circ}$, and consumed the most energy at $120^{\circ}$ (Figure 4). Hence, the azimuth of $120^{\circ}$ should be avoided in the design of ski slope.

Figure 5 shows the monthly energy consumption of the ski slope. It can be seen that the building consumed the least energy in February and the most in July; the energy consumption was quite different between winter and summer; 
The period from June to September accounted for half the annual energy consumption. Therefore, summer is the critical period to energy conservation of ski slope.

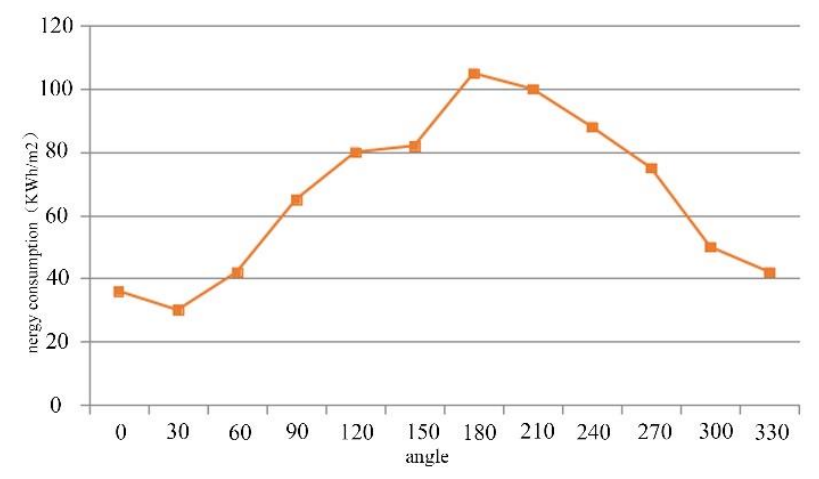

Figure 5. Monthly energy consumption of the building

\section{CONCLUSIONS}

The building orientation is a major influencing factor of the energy consumption of ski slopes in hot summer and cold winter region. During the design of such a building, it is necessary to quantitatively analyse the environment of the building site. The designer must attach great importance to the orientation in the energy-saving design and ensure the rationality in the orientation design for ski slopes in hot summer and cold winter region. Meanwhile, the designer should take the initiative to compare various plans for building layout, aiming to fully tap the energy-saving potential of building orientation. In this way, the ski slopes can truly integrate into and coexist with the surrounding environment, laying the basis for healthy and sustainable development.

\section{ACKNOWLEDGMENT}

National Key R\&D Program "Key Technology for Liveable Improvement and Function Upgrading of Existing Residential Buildings" (2017YFC0702900), Hunan Graduate Research Project 2017 (CX2017B092), Hunan Natural Science Foundation (2016JJ4017, 2016JJ4019).

\section{REFERENCES}

[1] Katayama M. (2002). Indoor ski ground facilities having lighting fixtures. United States Patent.

[2] Inoue M, kishi S. (1993). Floor structure for indoor artificial skiing ground. United States Patent (19): 5199815.

[3] Kovach BF. (1984). Method of using frozen salt water to maintain a low cost, low energy consuming indoor or outdoor ice rink. United States Patent (19).

[4] Aragón-Correa JA, Hurtado-Torres N, Sharma S, GarciaMorales VJ. (2008). Environmental strategy andperformance in small firms: A resource-based perspective. Journal of Environmental Management 86(1): 88-103 https://doi.org/10.1016/j.jenvman.2006.11.022

[5] Assaf AG, Josiassen A. (2011). Identifying and rankingthe determinants of tourism performance: A global investigation. Journal of Travel Research 51(4): 388-399. https://doi.org/10.1177/0047287511426337

[6] Arros CP, Botti L, Peypoch N, Robinot E, Solonandrasana B, George AA. (2011). Performance of french destinations: tourism attraction perspectives. Tourism Management 32(1): 141-146. https://doi.org/10.1016/j.tourman.2010.01.015

[7] Clemens B, Douglas YJ. (2006). Does coercion drive firmsto adopt voluntary green initiatives? relationships among coercion, superior firm resources, and voluntary green initiatives. Journal of Business Research 59(4): 483-491. https://doi.org/10.1016/j.jbusres.2005.09.016

[8] Klassen RD, Whybark DC. (1999). Environmental management in operations: The selection of environmental technologies. Decision Sciences 30(3): 601-631. https://doi.org/10.1111/j.15405915.1999.tb00900.x

[9] Becken S, Simmons DG. (2002). Understanding energy consumption patterns of tourist attractions and activities in New Zealand. Tourism Management 23(4): 343-354. https://doi.org/10.1016/S0261-5177(01)00091-7

[10] Chen H, Zou TH. (2001). Design and energy conservation of indoor ski dome. Journal of TianJin University of Commerce 3(5): 15-17.

[11] Yu T, Hu XW, Lv BY, Ma M. (2016). Study on the relationship between the humiture and the fog in indoor ice rink. Refrigeration (2): 47-49.

[12] Gu HD. (2011). Design Strategy for Energy Saving of Indoor Ski Slope. Chongqing, Chongqing University.

[13] Sun X. (2014). Rsearch on Ecological Design of Winter Sports Buildings. Harbin, Harbin Institute of Technology.

[14] Guo BR. (2017). Study on Energy-saving Design of Fresh Air Dehumidification System in Ice Rink. Harbin, Harbin Institute of Technology.

[15] Beyazi MF, Koc E. (2009). An analysis of snow options for ski resort establishments. Tourism Management 31(5): 676-683. https://doi.org/10.1016/j.tourman.2009.07.012

[16] Hathroubi S, Peypoch N, Robinot E. (2014). Technical efficiency and environnemental management: The tunisian case. Journal of Hospitality and Tourism Management 21(1): 27-33. https://doi.org/10.1016/j.jhtm.2014.03.002

[17] Goncalves O, Robinot E, Michel H. (2016). Does it pay to be green? The case of french ski resorts. Journal of Travel Research 55(7): 889-903. https://doi.org/10.1177/0047287515601238

[18] Molina-Azorín JF, Claver-Cortés E, Pereira-Moliner J, Tarí JJ. (2009). Environmental practices and firm performance: An empirical analysis in the spanish hotel industry. Journal of Cleaner Production 17(5): 516-524. https://doi.org/10.1016/j.jclepro.2008.09.001

[19] Zelenyuk V, Zheka V. (2006). Corporate governance and firm's efficiency: The case of a transitional country, Ukraine. Journal of Productivity Analysis 25(1-2): 143157. https://doi.org/10.1007/s11123-006-7136-8

[20] Assaf A. (2009). Bootstrapped scale efficiency measures of UK airports. Journal of Air Transport Management 16(1): 42-44. https://doi.org/10.1016/j.jairtraman.2009.03.001

[21] Klusiewicz A, Faff J, Starczewska-Czapowska J. (2011). Prediction of maximal oxygen uptake from submaximal and maximal exercise on a ski ergometer. Biology of Sport 28(1): 31-35. https://doi.org/10.5604/935870 
[22] Medina YC, Khandy NH, Carlson KM, Fonticiella OMC, Morales OFC. (2018). Mathematical modeling of twophase media heat transfer coefficient in air cooled condenser systems. International Journal of Heat and Technology 36(1): 319-324.

https://doi.org/10.18280/ijht.360142

[23] Liu L, Shi YG, Long Y, Zhao JZ, Chen J, Cui YJ. (2016). Greenhouse environment inspection vehicle control system design based on ZigBee. Mathematical
Modelling of Engineering Problems 3(4): 184-190. https://doi.org/10.18280/mmep.030406

[24] Losnegard T, Hallén J. (2013). Physiological differences between sprint-and distance-specialized cross-country skiers. International Journal of Sports Physiology \& Performance 9(1): 25-31.

https://doi.org/10.1123/ijspp.2013-0066

[25] Xia B, Chan A. (2008). Review of the design-build market in the People's Republic of China. J. Constr. Procurement (14)2: 108-117. 